\title{
Antibody dependent enhancement of frog virus 3 infection
}

\author{
Heather E Eaton, Emily Penny, Craig R Brunetti
}

\begin{abstract}
Background: Viruses included in the family Iridoviridae are large, icosahedral, dsDNA viruses that are subdivided into 5 genera. Frog virus 3 (FV3) is the type species of the genus Ranavirus and the best studied iridovirus at the molecular level. Typically, antibodies directed against a virus act to neutralize the virus and limit infection. Antibody dependent enhancement occurs when viral antibodies enhance infectivity of the virus rather than neutralize it.

Results: Here we show that anti-FV3 serum present at the time of FV3 infection enhances infectivity of the virus in two non-immune teleost cell lines. We found that antibody dependent enhancement of FV3 was dependent on the Fc portion of anti-FV3 antibodies but not related to complement. Furthermore, the presence of anti-FV3 serum during an FV3 infection in a non-immune mammalian cell line resulted in neutralization of the virus. Our results suggest that a cell surface receptor specific to teleost cell lines is responsible for the enhancement.

Conclusions: This report represents the first evidence of antibody dependent enhancement in iridoviruses. The data suggests that anti-FV3 serum can either neutralize or enhance viral infection and that enhancement is related to a novel antibody dependent enhancement pathway found in teleosts that is Fc dependent.
\end{abstract}

\section{Background}

Following a viral infection an immune response is elicited by the host, which includes both an innate and adaptive response. During the adaptive immune response, antibodies are produced that are designed to recognize and neutralize a pathogen. Typically, viral antibodies neutralize a virus by preventing the attachment of specific cell surface receptors with viral glycoproteins, while also activating the complement system. However, not all antibodies serve to reduce infectivity. Antibody dependent enhancement (ADE) occurs when viral antibodies enhance infectivity of a virus by promoting the attachment of viral particles to cells. Virus specific antibodies bind to viral particles to form complexes that can bypass normal routes of viral attachment and entry. The virus+antibody complex allows for increased viral entry or infection of cells that would not normally become infected. Virus+antibody complexes therefore result in a more efficient infection than with virus alone.

There are several mechanisms of how ADE can occur. The most common mechanism of ADE is Fc receptor (FcR)-dependent [1]. In FcR-dependent ADE the virus

\footnotetext{
* Correspondence: craigbrunetti@trentu.ca

Department of Biology, Trent University, Peterborough, ON, K9J 7B8, Canada
}

+antibody complex binds to cells containing FcRs on their surface. The interaction is mediated between the exposed Fc region of the antibody (from the virus+antibody complex) and the FcR on the cell surface. FcRs are found on a wide variety of cells of the immune system, including macrophages, B cells, neutrophils, monocytes, and granulocytes $[2,3]$. However, since not all cells that exhibit ADE are immune cells, another mechanism must be responsible for ADE in non-FcR bearing cells. Complement-mediated ADE is not exclusive to FcR bearing cells because complement receptors are found on a large variety of cell types [4]. Complementmediated $\mathrm{ADE}$ occurs via binding between the Fc region of antibodies and C1q [1]. This can result in a variety of outcomes including the activation of complement, which causes complement $\mathrm{C} 3$ fragment and viral surface proteins to bind and promote viral attachment. C1q can also enhance virus attachment by binding to $\mathrm{C} 1 \mathrm{qR}$ on the cell surface, which brings the virus into close proximity to cells.

$\mathrm{ADE}$ can result in increased viral pathogenesis because it enhances a virus's ability to bind to cells. It therefore can result in increased severity of disease. This was first shown with dengue virus where a second infection 
resulted in an increased number of infected cells and higher levels of virus production [5,6]. An in vitro study suggested that the mechanism behind ADE in dengue virus was FcR-dependent [7-9]. Dengue virus titer was enhanced dramatically through the binding of the virus +antibody complex to FcRs found on cells of the immune system [7-9].

While ADE has been demonstrated for many RNA viruses, only a few DNA virus families, including poxviruses [10] and herpesviruses [11-13] have been shown to use ADE as a mechanism of infection. While it is suggested that they most likely use FcR-dependent ADE [1], little is actually known about the mechanism of $\mathrm{ADE}$ in the large DNA viruses. We decided to determine if viruses from the family Iridoviridae use ADE as a mechanism of infection. Viruses in the family Iridoviridae are large ( 120-200 $\mathrm{nm})$, icosahedral viruses that contain a linear, double-stranded DNA genome. Iridovirus infections appear to be restricted to invertebrates (Iridovirus, Chloriridovirus) and poikilothermic vertebrates (Lymphocystivirus, Ranavirus, Megalocytivirus) [14]. Although iridoviruses are large DNA viruses, very little is known about their biology. Using frog virus 3 (FV3; Ranavirus) as a model virus, we propose to investigate whether ADE occurs in viruses of the family Iridoviridae, specifically in the Ranavirus genus.

\section{Results}

\section{ADE increases FV3 infection in teleost cells}

In order to investigate whether ADE occurs during an FV3 infection, FV3 was pre-incubated with either rabbit anti-FV3 serum (FV3+anti-FV3 serum) or rabbit preimmune serum (FV3+pre-immune serum). The FV3 tanti-FV3 serum and FV3+pre-immune serum complexes were added to BF-2 (teleost fibroblast) or FHM (teleost epithelial) cells. Two hours post-infection, BF-2 and FHM cells were overlaid with agarose and 48 hours later the number of plaques produced by the virus were counted and compared to the number of plaques from an FV3 only control infection. All experiments were repeated in at least 3 independent trials and mean results are shown (Figure 1A, Additional file 1A). The addition of $100 \mathrm{ng}$ of anti-FV3 serum to the virus in BF- 2 cells resulted in an $\sim 300 \%$ increase in the number of plaques compared to pre-immune serum (Figure 1A). Following the addition of the highest concentration of anti-FV3 serum (300 ng), we found that the plaque number was reduced as compared to an FV3 control indicating that at high concentrations, anti-FV3 serum can neutralize the infection (Figure 1A). Infection of cells by FV3+anti-FV3 serum complexes also increased the number of plaques in BF-2 cells compared to an infection with FV3+pre-immune serum complexes as seen by immunofluorescence (Figure 1B). Anti-FV3 serum staining revealed small plaques in cells infected with FV3+ pre-immune serum complexes while cells infected with FV3+anti-FV3 serum complexes showed more frequent and larger sized plaques (Figure 1B). A control experiment in which pre-immune serum or anti-FV3 serum were added to cells without FV3 resulted in an absence of plaques. In another teleost cell line (FHM), we observed a greater than $200 \%$ increase in the number of plaques in the presence of $100 \mathrm{ng}$ of anti-FV3 serum (Figure 1C, Additional file 1B). This data suggests that ADE occurs during an FV3 infection in teleost cells.

\section{Anti-FV3 serum neutralizes infection in BGMK cells}

FV3 replicates in a variety of cell types including cells of mammalian origin [15]. In order to determine whether the ADE phenomenon occurs in mammalian cells along with teleost cells, we pre-incubated FV3 with anti-FV3 serum or pre-immune serum and FV3+anti-FV3 serum or FV3+pre-immune serum complexes were added to BGMK (mammalian fibroblast) and BF-2 (teleost fibroblast) cells and the cells were overlaid with agarose. Forty-eight hours later, the overlay was removed and indirect immunofluorescence was used to visualize plaques. In contrast to teleost cells (Fig 1A), the addition of $100 \mathrm{ng}$ of anti-FV3 serum to mammalian cells resulted in an $\sim 90 \%$ reduction in the number of plaques compared to the pre-immune serum control (Figure 2A, Additional file 2). Furthermore, the plaques produced by an FV3 infection in BGMK cells were considerably smaller than those seen in BF-2 cells (Figure 2B). These results suggest that in mammalian cells anti-FV3 serum does not enhance an FV3 infection but instead neutralizes it. Thus, ADE does not occur in an FV3 infection in mammalian fibroblast cells but does occur in teleost fibroblast cells.

\section{Addition of pre-immune serum to BF-2 cells inhibits ADE of FV3 infectivity}

In order to determine if the ADE was specific to anti-FV3 serum, we challenged cells with non-specific rabbit serum to act as a competitive inhibitor of anti-FV3 serum. FV3+anti-FV3 serum (50 ng) or FV3+preimmune serum $(50 \mathrm{ng}$ ) complexes were allowed to form and were then added to cells along with increasing amounts (0-1000 ng total serum) of non-specific rabbit serum. Infected cells were incubated for 2 hours and overlaid with agarose. Forty-eight hours later the plaques were counted. The addition of increasing amounts of non-specific competitive serum resulted in a reduction in ADE (Figure 3, Additional file 3). At the highest concentration of competitor, $1000 \mathrm{ng}$ (20-fold excess), there was an almost $300 \%$ reduction of FV3 ADE (Figure 3 ) as compared to cells where pre-immune serum was not 

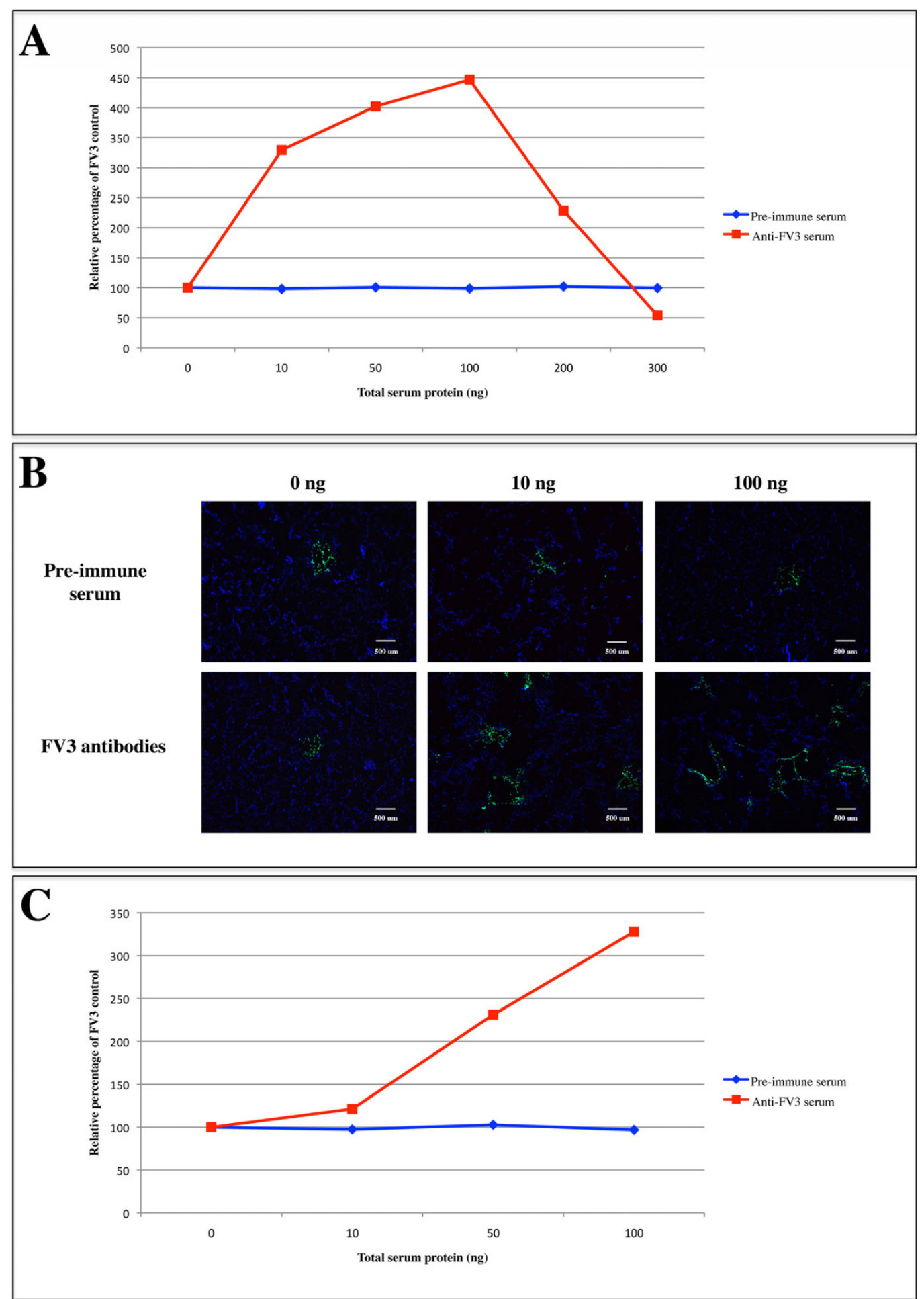

Figure 1 ADE occurs during an FV3 infection in teleost cells. FV3 ( 50 PFU) was incubated alone, with rabbit anti-FV3 serum, or rabbit preimmune serum for 1 hour at $4^{\circ} \mathrm{C}$ and was then added to BF-2 or FHM cells. (A) Two hours post-infection, BF-2 cells were overlaid and 48 hours later the plaques were stained with crystal violet and were counted. Plaque numbers are shown as a relative percentage of a control FV3 infection in the absence of serum. (B) Forty-eight hours post-overlay BF-2 cells were stained by indirect immunofluorescence using anti-FV3 serum (green) and DAPI (nuclei - blue). (C) FV3+anti-FV3 serum or FV3+rabbit pre-immune serum complexes were added to FHM cells and 24 hours later plaques were visualized by indirect immunofluorescence and counted. Plaque numbers were expressed as a relative percentage compared to FHM cells infected with FV3 only. All experiments were completed in 3 independent trials and mean plaque numbers are shown. 

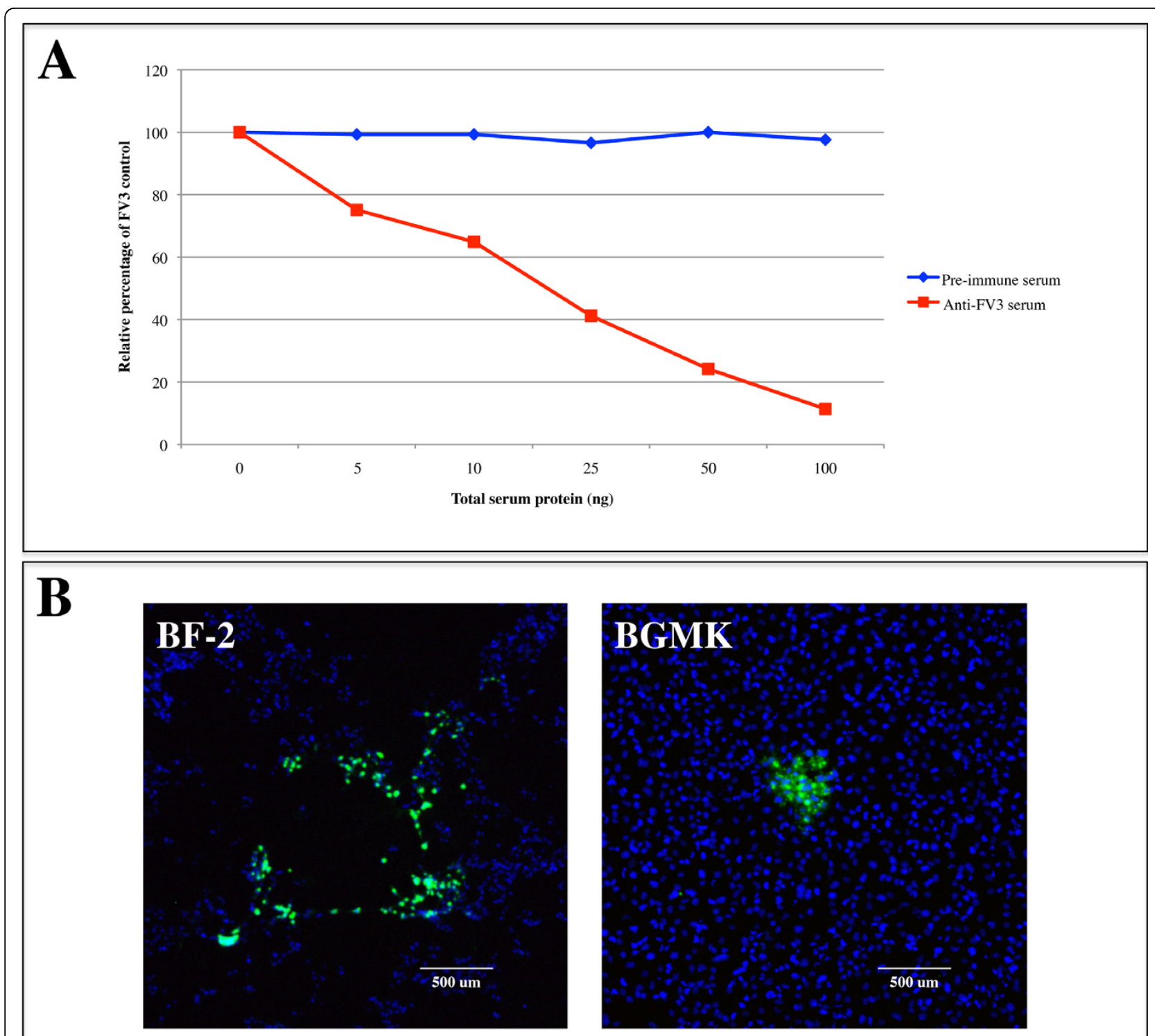

Figure 2 Rabbit anti-FV3 serum neutralizes an FV3 infection in a mammalian cell line. Rabbit anti-FV3 serum (0-100 ng) or rabbit preimmune serum (0-100 ng) was incubated with FV3 ( 50 PFU) before being added to BGMK or BF-2 cells for 2 hours. Once infected, BGMK cells were incubated at $28^{\circ} \mathrm{C}$ with $5 \% \mathrm{CO}_{2}$. The cells were subsequently overlaid with agarose. (A) Forty-eight hours post-overlay BGMK cells underwent indirect immunofluorescence and plaques were counted. Plaque numbers from 3 independent trials were counted and mean plaque values were compared to BGMK cells infected with FV3 only and values are shown as a relative percentage. (B) Forty-eight hours post-overlay, BGMK and BF-2 cells were processed for indirect immunofluorescence using rabbit anti-FV3 serum (green) and DAPI (nuclei - blue).

added (Figure 3: $0 \mathrm{ng}$ ). These results suggest that the non-specific serum acts as a competitive inhibitor presumably binding to cell surface components that mediate ADE.

\section{Protein A eliminates ADE of FV3 infectivity}

Since ADE occurs in an FV3 infection in teleost cells, we next wanted to determine if the Fc portion of antiFV3 antibodies mediates ADE. Protein A binds to the
Fc region of an antibody, thereby blocking binding between the Fc region of the antibody and FcRs and complement proteins on the cell surface. Protein A (300 $\mu \mathrm{g} / \mathrm{mL}$ ) was pre-incubated with rabbit anti-FV3 serum or rabbit pre-immune serum followed by the addition of FV3. FV3+anti-FV3 serum/(+/-)protein A or FV3+preimmune serum $/(+/-)$ protein A complexes were added to cells and plaques were counted 48 hours later. The addition of protein A to anti-FV3 serum completely 


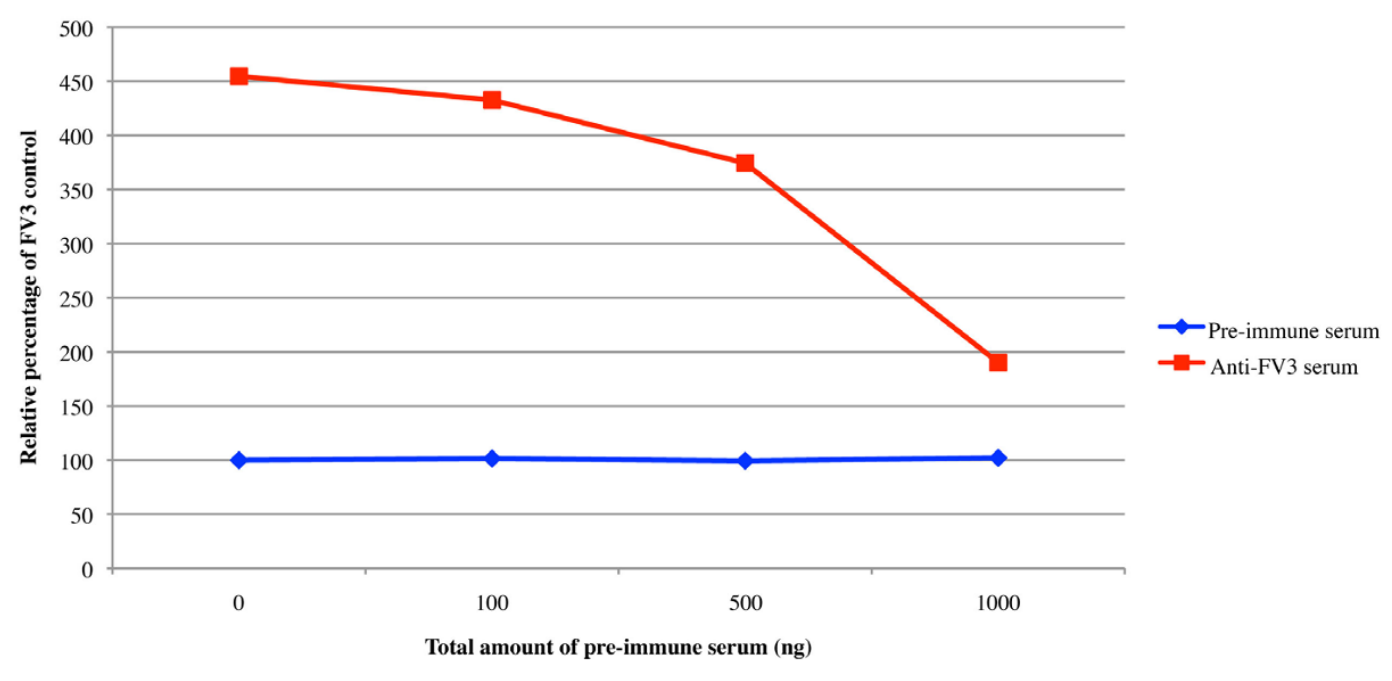

Figure 3 Addition of rabbit pre-immune serum to BF-2 cells inhibits ADE. FV3 ( 50 PFU) was incubated with either $50 \mathrm{ng}$ of rabbit antiFV3 serum or 50 ng rabbit pre-immune serum. FV3+anti-FV3 serum or FV3+pre-immune serum complexes were added to BF-2 cells along with varying amounts of pre-immune serum (0-1000 ng). Cells were overlaid and plaques were visualized with crystal violet. Mean plaques values from 3 independent trials were obtained and mean values were expressed as a relative percentage to BF-2 cells infected with FV3 in the absence of anti-FV3 serum or pre-immune serum.

abolished the ADE in BF-2 cells (Figure 4A, Additional file $4 \mathrm{~A}$ ). Note that the abolishment in infectivity by protein $A$ is so complete that the virus samples incubated with protein $A$ are indistinguishable from the preimmune control (Figure 4A). These results suggest that the Fc portion of anti-FV3 antibodies is responsible for mediating ADE. However, the addition of protein A to serum can sometimes result in aggregation of the antibodies, thereby reducing the amount of available antibody. In order to avoid this issue we incubated $300 \mu \mathrm{g} /$ $\mathrm{mL}$ of protein $\mathrm{A}$ on $\mathrm{BF}-2$ cells for 30 minutes prior to the addition of FV3+anti-FV3 serum or FV3+preimmune serum complexes. Forty-eight hours post-infection plaques were counted. The addition of protein A to BF-2 cells prior to addition of anti-FV3 serum allowed FV3+anti-FV3 serum complexes to form. However, we obtained a complete abolishment of enhancement similar to that seen when protein A was pre-incubated with FV3+anti-FV3 serum (Figure 4A, Additional file 4B). These results suggest that ADE of FV3 infectivity can be inhibited by protein A and is likely Fc-dependent.

\section{ADE of FV3 infectivity is complement-independent}

To determine whether FV3 ADE was complementdependent, anti-FV3 serum and pre-immune serum were heat-inactivated to inactivate complement, or incubated with either EGTA or zymosan A. EGTA is a chelator that inhibits the classical complement pathway, while zymosan A disrupts the alternative complement pathway. Treated anti-FV3 serum or pre-immune serum was incubated with FV3 before addition to BF-2 cells. Forty-eight hours post-overlay plaques were counted. Infection by the FV3+anti-FV3 serum complexes treated with heat-inactivation, EGTA, or zymosan A did not reduce the ADE of FV3 infectivity as compared to the untreated FV3+anti-FV3 serum control (Figure 4B, Additional file 5A, 5B, 5C). Regardless of whether high or low levels of complement activity were present at the time of infection, enhancement was not affected by complement inhibitors suggesting that inactivation of complement does not disrupt ADE of FV3 infectivity.

\section{Fc binding proteins on teleost cells}

The ability of anti-FV3 serum to neutralize an infection in BGMK cells (mammalian fibroblast) and enhance infection in BF-2 and FHM cells (teleost fibroblast and epithelial respectively) suggests that teleost cells may contain an Fc-binding component absent from BGMK cells. Since the pre-immune control serum was able to act as a competitive inhibitor (Figure 3), it suggests that there must be a specific component on teleost cells that the serum is binding to. A western blot containing BGMK, BF-2, and FHM cellular extracts was probed with rabbit pre-immune serum to determine if the serum bound to any cellular proteins. While rabbit serum was unable to bind to any proteins in BGMK 


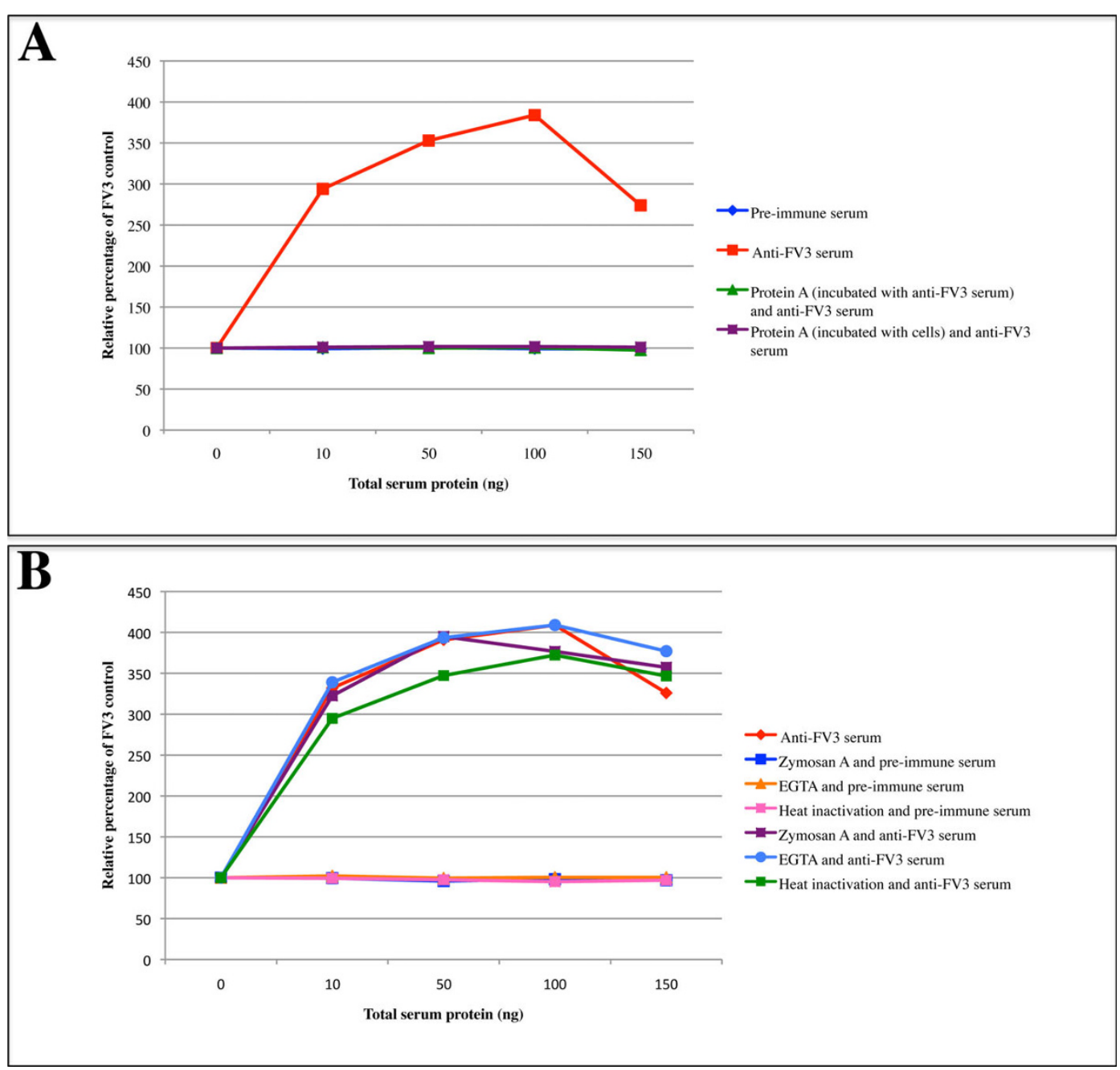

Figure 4 ADE in FV3 is Fc-dependent and independent of complement. (A) Protein A $(300 \mu \mathrm{g} / \mathrm{mL}$ ) was either incubated with BF-2 cells or anti-FV3 serum and pre-immune serum for 30 minutes at room temperature. FV3 ( 50 PFU) was incubated with anti-FV3 serum or pre-immune serum and was then added to BF-2 cells (+/- protein A) and were overlaid 2 hours later. FV3 ( 50 PFU) was incubated with anti-FV3 serum or pre-immune serum (+/- protein A) and then was added to BF-2 cells and were overlaid 2 hours later. Forty-eight hours post-overlay plaques were counted and expressed as a relative percentage of a control FV3 infection. (B) Rabbit anti-FV3 serum or rabbit pre-immune serum were heat-inactivated or incubated with zymosan A or EGTA for one hour before the addition of FV3 ( 50 PFU). FV3+anti-FV3 serum or FV3+preimmune serum complexes were added to BF-2 cells, which were subsequently overlaid. Forty-eight hours post-overlay, plaques were counted and were compared as a relative percentage to BF-2 cells infected with FV3 in the absence of serum. Experiments were completed in at least 3 independent trials with mean plaque values shown.

cells (which do not undergo ADE), two bands at 38 and $95 \mathrm{kDa}$ were detected in BF-2 and FHM cells probed with rabbit pre-immune serum (Figure 5A). No bands were detected either on a control blot where the primary rabbit serum was omitted (Figure $5 \mathrm{C}$ ) or on a membrane where pre-immune serum was pre-incubated with protein A (Figure 5B), which binds to the Fc portion of the antibody. These data suggest that the Fc portion of the antibody bound to the $38 \mathrm{kDa}$ and $95 \mathrm{kDa}$ proteins and that the variable region of the antibody does not mediate this interaction. The experiment was repeated several times using an unrelated rabbit serum and results consistent with Figure 5 were obtained (data not shown). This data suggests that an Fc binding component specific to fibroblast and epithelial teleost cells may play a role in ADE of an FV3 infection.

\section{Discussion}

While ADE has been previously reported for some large DNA viruses, including herpesviruses [11-13] and poxviruses [10], no studies to date have demonstrated ADE as a mechanism to enhance infections in iridoviruses. This paper provides the first evidence of ADE in iridoviruses, specifically in the Ranavirus genus. 


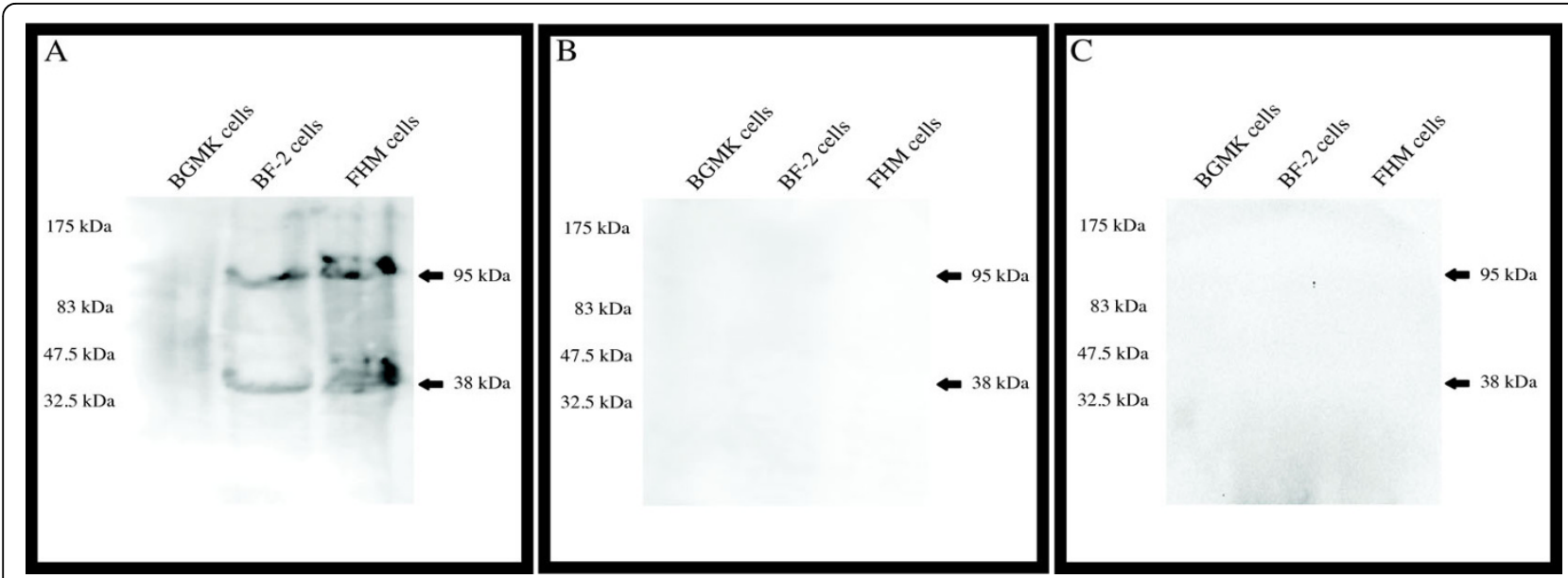

Figure 5 Rabbit serum binds to two proteins ( $38 \mathrm{kDa}$ and $\mathbf{9 5} \mathbf{k D a}$ ) on teleost cells. BGMK, BF-2, and FHM cells were harvested and run on a 10\% SDS acrylamide gel. Proteins were transferred from the gel to a PVDF membrane. The membrane was probed with (A) rabbit preimmune serum, (B) rabbit pre-immune serum pre-incubated with protein A, or (C) no primary serum was added. Proteins were then visualized using peroxidase conjugated goat anti-rabbit lgG and chemiluminescence.

In this study, anti-FV3 serum demonstrated the ability to either neutralize or enhance an FV3 infection depending on the cell line. Although the infection was less efficient in mammalian cells, FV3 exhibited the ability to enter the cell and spread as was revealed by the presence of numerous plaques post-infection. The addition of anti-FV3 serum to an FV3 infection in BGMK cells dramatically reduced plaque number and size demonstrating the ability of the anti-FV3 serum to neutralize the infection in a mammalian cell line. However, the opposite effect was seen in teleost (BF-2 and FHM) cell lines. ADE often occurs with neutralizing antibodies at sub-neutralizing concentrations and differences in the interaction between virus and antibody can lead to either neutralization or enhancement of a viral infection [16]. Furthermore, enhancement of an infection is particularly sensitive to this interaction and can also involve the target cell. Our data suggests that the anti-FV3 serum used in this study possess both neutralizing and enhancing activity, depending on various factors including the cell type and the concentration of antibody.

Ranaviruses, including FV3, have been isolated from a variety of species including fish and amphibians. While FV3 has never been isolated from fish in vivo, other closely related (over $98 \%$ sequence identity of the major capsid protein [17]) ranaviruses, including epizootic haematopoietic necrosis virus (EHNV) and Bohle virus (BIV) infect fish and infection can result in high levels of morbidity and mortality [18-20]. FV3 shows high levels of infectivity in fish cell lines in vitro [21-23]; therefore two fish cells lines (BF-2 and FHM) were used during this study. While there are many differences from mammalian immune systems, the immune systems of fish and amphibians are fundamentally similar to mammals with both innate immunity and adaptive immune functions $[24,25]$. However, immunoglobins of lower vertebrates are currently poorly understood as compared to those of mammals. Fish were the first group to have demonstrated antibody activity and have one predominant Ig isotype, an IgM-like tetrameric molecule [26]. Amphibians have several isotypes including IgY, which is the predominant isotype in amphibians and is considered the functional equivalent to mammalian IgG [27-29]. However, the adaptive immune system of mammals is fundamentally similar to that of lower vertebrates and is characterized by $\mathrm{T}$ cell receptors, Ig, and the major histocompatibility complex (MHC). Lower vertebrates also rely heavily on non-specific defense systems for pathogen defense and therefore the innate immune system of lower vertebrates, including complement, is diverse and similar to that of higher vertebrates. We therefore suspect that the mechanisms behind ADE in fish and amphibians will be similar to that of mammals. While we feel the mechanisms behind ADE to be similar between fish, amphibians, and mammals, there are some inherent differences between the immune systems of each species. It will be important to confirm these experiments in the future using sera from either immunized frogs or fish.

Common mechanisms behind ADE can be dependent on either complement or FcRs. Our results suggest that complement pathways (classical or alternative) do not play a role in the enhancement of FV3 infection by antiFV3 serum. However, protein A eliminated any enhancement of the anti-FV3 serum suggesting the mechanism behind FV3 ADE to be FcR-dependent. 
Many virus families, including other DNA viruses, enhance viral infection through the binding of the Fc region of anti-viral antibodies to FcR on the surface of cells of the immune system [30-37]. However, this result is intriguing because both cell lines that exhibited ADE (BF-2 and FHM) in this study are non-immune (fibroblast and epithelial, respectively) cell lines that should lack FcR on the cell surface $[2,3,9]$. While recent research suggests that teleosts and amphibians possess both FcR homologs and novel immune-type receptors (NITRs) [38-42], little is known about their tissue distribution and role in innate immunity. FcRs in humans are a variety of sizes that can range from $40 \mathrm{kDa}$ to over 70 $\mathrm{kDa}$ [43-46], while one previously identified FcR in fish was predicted to be $\sim 33 \mathrm{kDa}$ in size [40]. We identified two proteins $(38 \mathrm{kDa}$ and $95 \mathrm{kDa})$ in teleost cells (but not in a mammalian cell line) that bound to the Fc region of rabbit antibodies. The molecular weight of these proteins does not rule out the possibility that they may function as novel FcRs in teleosts. While we do not specifically know what the anti-FV3 serum is binding to mediate ADE, the results suggest that proteins specific to teleost cells bind to the $\mathrm{Fc}$ region of antibodies potentially mediating ADE.

Iridovirus infections of increased pathogenicity have been recently observed in several wild and cultivated fish and amphibian species $[17,47,48]$. Specifically, ranavirus infections pose a potential threat to amphibians and have been implicated in the widespread decline of worldwide amphibian populations [48,49]. There have recently been increasing reports of ranavirus infections, with both the severity of infections and the number of species infected increasing [17,50-55]. While evidence suggests that an iridovirus infection mounts a strong immune response [56,57], this does not eliminate the possibility that viral infection can be enhanced under certain circumstances. Although humoral immunity is required for protection against viruses, antibodies at sub-neutralizing concentrations may enhance, rather than protect against infection [16]. It is also possible that the virus utilizes ADE as a method for more efficient entry. Regardless of whether a strong immune response is mounted, ADE may promote increased entry or entry into cells not usually infected. In particular, $\mathrm{ADE}$ in immunocompromised individuals may allow for increased infection. Furthermore, the link between ADE in vitro and in vivo currently remains elusive. For instance, ADE of dengue viruses has been well documented and extensively characterized in vitro, but in vivo studies remain unclear and controversial [58-60]. It will be important for future experiments to confirm these in vitro studies using live fish and frogs. Ranavirus infections are spreading rapidly worldwide, however, the reasons behind this rapid spread are currently unknown and are most likely complex. While FV3 ADE has yet to be demonstrated in vivo, a strong second infection of FV3 may explain the increased severity and prevalence of ranavirus infections. Therefore, ADE may represent a potential hypothesis for the recent emergence and increased severity of ranavirus infections.

\section{Conclusions}

This study demonstrates for the first time that FV3, an iridovirus, utilizes ADE to increase infection in vitro. The anti-FV3 serum used in this study both enhanced and neutralized a viral infection depending on cell type and concentration. The mechanism behind enhancement was found to be independent of complement but dependent upon the Fc region of anti-FV3 antibodies. The addition of protein A to either anti-FV3 serum or teleost cells completely abolished ADE. This result was surprisingly because two non-immune cell lines most likely lacking $\mathrm{FcR}$ were used during this experiment. Our results suggests that the Fc region of anti-FV3 antibodies may promote viral entry through novel Fc binding activity on teleost cells.

\section{Methods \\ Cell lines and virus}

Bluegill fry (BF-2) cells were obtained from American Type Culture Collection (ATCC, Manassas, VA) and were grown at $28^{\circ} \mathrm{C}$ in $5 \% \mathrm{CO}_{2}$ in Eagle's Minimal Essential medium with Earle's balanced salts (EMEM; HyClone, Ottawa, ON) and $2 \mathrm{mM} \mathrm{L}$-glutamine supplemented with $10 \%$ fetal bovine serum (FBS), $1.0 \mathrm{mM}$ sodium pyruvate, $0.1 \mathrm{mM}$ nonessential amino acids, and antibiotics $(100 \mathrm{U} / \mathrm{mL}$ penicillin and $100 \mathrm{~g} / \mathrm{mL}$ streptomycin). Baby green monkey kidney (BGMK) cells were obtained from ATCC and were maintained in Dulbecco's modified Eagle's medium (DMEM; HyClone) supplemented with 7\% FBS, $2 \mathrm{mM}$ L-glutamine, penicillin $(100 \mathrm{U} / \mathrm{mL})$, and streptomycin $(100 \mathrm{~g} / \mathrm{mL})$ at $37^{\circ} \mathrm{C}$ with $5 \% \mathrm{CO}_{2}$. We have previously characterized an FV3 infection in BGMK cells [61]. Fathead minnow (FHM) cells were also obtained from ATCC and were maintained at $30^{\circ} \mathrm{C}$ in minimum essential medium with Hanks' salts (MEM; Invitrogen, Burlington, $\mathrm{ON}$ ) supplemented with $10 \% \mathrm{FBS}$, penicillin $(100 \mathrm{U} / \mathrm{mL})$, and streptomycin $(100 \mathrm{~g} / \mathrm{mL})$. FV3 was obtained from ATCC and rabbit anti-FV3 serum and rabbit pre-immune serum were kindly provided by V.G. Chinchar (University of Mississippi Medical Center, Jackson, MS). Once BGMK cells were infected with FV3 they were incubated at $28^{\circ}$ $\mathrm{C}$ with $5 \% \mathrm{CO}_{2}$.

\section{ADE plaque assay}

FV3 ( 50 PFU) was mixed with either rabbit anti-FV3 serum or control rabbit pre-immune serum $(0 \mathrm{ng}, 10$ 
ng, $50 \mathrm{ng}, 100 \mathrm{ng}, 200 \mathrm{ng}$, and $300 \mathrm{ng}$ total serum protein) for a final volume of $100 \mu \mathrm{L}$ in media and was incubated for 1 hour at $4^{\circ} \mathrm{C}$. The FV3+anti-FV3 serum or FV3+pre-serum complexes were then added to BF-2, FHM, or BGMK cells grown to $90 \%$ confluence in 6well plates. BF-2 and BGMK cells were overlaid with $2 \%$ agarose 2 hours post-infection. Forty-eight hours postoverlay cells were either stained with crystal violet $(0.05 \%)$ or underwent indirect immunofluorescence and plaques were counted. FHM cells were incubated for 24 hours and indirect immunofluorescence was carried out and plaques were counted.

\section{Pre-immune serum challenge}

Rabbit anti-FV3 serum (50 ng total serum protein) or rabbit pre-immune serum (50 ng total serum protein) were mixed with FV3 ( $50 \mathrm{PFU})$ in a final volume of $100 \mu \mathrm{L}$ in EMEM and were incubated for 1 hour at $4^{\circ} \mathrm{C}$. Pre-immune serum was added to BF-2 cells grown to $90 \%$ confluence in 6-well dishes for final concentrations of $0 \mathrm{ng} / \mu \mathrm{L}, 0.1 \mathrm{ng} / \mu \mathrm{L}, 0.5 \mathrm{ng} / \mu \mathrm{L}$, and $1 \mathrm{ng} / \mu \mathrm{L}$. FV3 +anti-FV3 serum or FV3+pre-immune serum complexes were added to BF- 2 cells containing pre-immune serum and were incubated for 2 hours. Cells were overlaid with $2 \%$ agarose and 48 hours post-overlay crystal violet $(0.05 \%)$ was added to cells and plaques were counted.

\section{Inhibition of $\mathrm{Fc}$ and complement}

Rabbit anti-FV3 serum (0-150 ng total serum protein) or rabbit pre-immune serum (0-150 ng total serum protein) were incubated with protein A $(300 \mu \mathrm{g} / \mathrm{mL}$; Sigma, Oakville, ON) or EGTA $(0.05 \mathrm{M})$ for 30 minutes at room temperature, zymosan A (20 mg/mL; Sigma) for 1 hour at $37^{\circ} \mathrm{C}$, or were heat-inactivated at $56^{\circ} \mathrm{C}$ for 30 minutes. Approximately 50 PFU of FV3 was added and the FV3+anti-FV3 serum or FV3+pre-immune serum complexes were brought up to a final volume of $100 \mu \mathrm{L}$ with serum-free EMEM. An ADE plaque assay in BF-2 cells was then performed. Protein A $(300 \mu \mathrm{g} / \mathrm{mL})$ was incubated with BF-2 cells for 30 minutes at room temperature. Cells were washed several times with PBS and 50 PFU of FV3 previously incubated with $0-150$ ng antiFV3 serum or pre-immune serum for one hour at $4^{\circ} \mathrm{C}$ were added to the cells. An ADE plaque assay using 0 ng, $10 \mathrm{ng}, 50 \mathrm{ng}, 100 \mathrm{ng}$, and $150 \mathrm{ng}$ of rabbit anti-FV3 serum or control rabbit pre-immune serum was then performed.

\section{Indirect immunofluorescence}

Cells were fixed for 10 minutes in $3.7 \%$ paraformaldehyde in phosphate buffer saline (PBS). Following several washes, cells were incubated in block buffer ( $5 \%$ bovine serum albumin (BSA) (w/v), $50 \mathrm{mM}$ Tris $\mathrm{HCl}(\mathrm{pH} 7.4)$, $150 \mathrm{mM} \mathrm{NaCl}, 0.5 \% \mathrm{NP}-40(\mathrm{v} / \mathrm{v}))$ overnight at $4^{\circ} \mathrm{C}$. Cells were incubated with rabbit anti-FV3 serum (dilution: 1/ 1000) for one hour at room temperature. Cells were then incubated in FITC-conjugated goat anti-rabbit immunoglobulin G (IgG) (dilution: 1/100) (Jackson ImmunoResearch Inc., West Grove, PA) and Texas Red $^{\circ}$-X Phalloidin (dilution 1/40) (Invitrogen) for one hour at room temperature. Finally, cells were incubated for 2 minutes in the nucleic acid stain DAPI (Invitrogen) diluted to $300 \mathrm{nM}$ in PBS. Immunofluorescence was detected using a Leica DM6000 B fluorescent microscope (Leica, Wetzlar, Germany). Images were assembled using Adobe Photoshop CS4 (Adobe, San Jose, CA).

\section{Western Blotting}

BGMK, BF-2, and FHM cells grown to $100 \%$ confluence in a 6-well dish were scraped into the media and centrifuged at $10,000 \times \mathrm{g}$ for 5 minutes. The supernatant was removed and the cells were re-suspended in Laemmli reducing buffer [62]. Cell lysates were boiled and proteins were separated on a $10 \%$ polyacrylamide gel using sodium dodecyl sulfate (SDS) running buffer (125 mM Tris, $1.25 \mathrm{M}$ glycine, $0.5 \%$ SDS). Following electrophoresis, the proteins were transferred from the gel to a polyvinylidene difluoride (PVDF) membrane using a semi-dry transfer apparatus (FisherBiotech, Pittsburgh, PA). The membrane was blocked overnight at $4^{\circ} \mathrm{C}$ in TBST buffer (140 mM NaCl, $24 \mathrm{mM}$ Tris (pH 7.4), 0.2\% Tween $20,3 \mathrm{mM} \mathrm{KCl}$ ) containing $5 \%$ non-fat milk powder. The membrane was incubated without primary serum, rabbit pre-immune serum (dilution 1:1000), rabbit pre-immune serum pre-incubated with $300 \mu \mathrm{g} / \mathrm{mL}$ protein $\mathrm{A}$ for 30 minutes at room temperature (dilution $1: 1000)$, or a second unrelated rabbit pre-immune serum (dilution 1:1000) for 1 hour shaking at room temperature. The membrane was washed several times then incubated for 1 hour shaking at room temperature in peroxidase-conjugated AffiniPure $\mathrm{F}\left(\mathrm{ab} \mathrm{b}^{\prime}\right) 2$ fragment goat anti-rabbit IgG (Jackson ImmunoResearchInc.) diluted $1 / 10,000$. The membrane was washed several times and proteins were detected by applying Chemiluminescence Reagent Plus (Perkin-Elmer, Boston, MA) to the membrane as per the manufacture's protocol. The images were then viewed using a Genius ${ }^{2}$ Bio Imaging System (Syngene, Frederick, MD).

\footnotetext{
Additional file 1: ADE occurs during an FV3 infection. ADE occurs during an FV3 infection in (A) BF-2 and (B) FHM cells. Original plaque numbers and standard error from three individual experiments are shown.

Click here for file

[http://www.biomedcentral.com/content/supplementary/1743-422X-7-41S1.XLS ]
} 
Additional file 2: Rabbit anti-FV3 serum neutralizes an FV3 infection in BGMK cells. Original plaque numbers and standard error from three individual experiments are shown.

Click here for file

[ http://www.biomedcentral.com/content/supplementary/1743-422X-7-41S2.XLS]

Additional file 3: Addition of rabbit pre-immune serum to BF-2 cells inhibits ADE. Original plaque numbers and standard error from three individual experiments are shown.

Click here for file

[ http://www.biomedcentral.com/content/supplementary/1743-422X-7-41S3.XLS ]

Additional file 4: ADE in FV3 is Fc-dependent. Protein $A$ incubated with either (A) anti-FV3 serum or (B) BF-2 cells abolished ADE in BF-2 cells. Original plaque numbers and standard error from three individual experiments are shown.

Click here for file

[http://www.biomedcentral.com/content/supplementary/1743-422X-7-41S4.XLS ]

Additional file 5: ADE in FV3 is complement independent. Treatment of anti-FV3 serum with (A) heat inactivation, (B) EGTA, and (C) zymosan A did not affect ADE. Original plaque numbers and standard error from

three individual experiments are shown.

Click here for file

[http://www.biomedcentral.com/content/supplementary/1743-422X-7-41S5.XLS ]

\section{Acknowledgements}

We thank Dr. V.G. Chinchar of the University of Mississippi Medical Center for generously providing the rabbit anti-FV3 serum and rabbit pre-immune serum. This work is supported by Discovery Grants (Natural Science and Engineering Research Council (NSERC) of Canada) to C.R.B. H.E.E. is the recipient of a NSERC postgraduate scholarship.

\section{Authors' contributions}

HEE performed the research and helped to draft the manuscript. EP helped to perform the research. CRB conceived the study and participated in its design and coordination and helped draft the manuscript. All authors read and approved the final manuscript.

\section{Competing interests}

The authors declare that they have no competing interests.

Received: 6 December 2009

Accepted: 18 February 2010 Published: 18 February 2010

\section{References}

1. Takada A, Kawaoka Y: Antibody-dependent enhancement of viral infection: molecular mechanisms and in vivo implications. Rev Med Virol 2003, 13:387-398.

2. Ravetch JV, Kinet JP. Fc receptors. Annu Rev Immunol 1991, 9:457-492.

3. Daeron M: Fc receptor biology. Annu Rev Immunol 1997, 15:203-234.

4. Ross GD: Complement receptors. Encyclopedia of Immunology San Diego: Academic PressRoitt IM, Delves PJ 1992, 388-391.

5. Sangkawibha N, Rojanasuphot $S$, Ahandrik S, Viriyapongse $S$, Jatanasen $S$, Salitul V, Phanthumachinda B, Halstead SB: Risk factors in dengue shock syndrome: a prospective epidemiologic study in Rayong, Thailand. I. The 1980 outbreak. Am J Epidemiol 1984, 120:653-669.

6. Halstead SB: Dengue haemorrhagic fever-a public health problem and a field for research. Bull World Health Organ 1980, 58:1-21.

7. Klimstra WB, Williams JC, Ryman KD, Heidner HW: Targeting Sindbis virusbased vectors to Fc receptor-positive cell types. Virology 2005, 338:9-21.

8. Rulli NE, Suhrbier A, Hueston L, Heise MT, Tupanceska D, Zaid A, Wilmes A, Gilmore K, Lidbury BA, Mahalingam S: Ross River virus: molecular and cellular aspects of disease pathogenesis. Pharmacol Ther 2005, 107:329-342.
9. Sullivan NJ: Antibody-mediated enhancement of viral disease. Curr Top Microbiol Immunol 2001, 260:145-169.

10. Hawkes RA, Lafferty KJ: The enchancement of virus infectivity by antibody. Virology 1967, 33:250-261.

11. Ghiasi H, Perng GC, Nesburn AB, Wechsler SL: Antibody-dependent enhancement of HSV-1 infection by anti-gK sera. Virus Res 2000, 68:137-144.

12. Inada T, Chong KT, Mims CA: Enhancing antibodies, macrophages and virulence in mouse cytomegalovirus infection. J Gen Virol 1985, 66:871-878.

13. Sixbey JW, Yao QY: Immunoglobulin A-induced shift of Epstein-Barr virus tissue tropism. Science 1992, 255:1578-1580.

14. Chinchar VG, Essbauer S, He JG, Hyatt A, Miyazaki T, Seligy V, Williams T: Family Iridoviridae. Virus Taxonomy Eight Report of the International Committee on Taxonomy of Viruses San Diego: Academic PressFauquet CM, Mayo MA, Maniloff J, Desselberger U, Ball LA 2005, 145-162.

15. Granoff A: Viruses of amphibia. Curr Top Microbiol Immunol 1969, 50:107-137.

16. Burton DR, Williamson RA, Parren PW: Antibody and virus: binding and neutralization. Virology 2000, 270:1-3.

17. Hyatt AD, Gould AR, Zupanovic Z, Cunningham AA, Hengstberger S, Whittington RJ, Kattenbelt J, Coupar BE: Comparative studies of piscine and amphibian iridoviruses. Arch Virol 2000, 145:301-331.

18. Langdon JS, Humphrey JD, Williams LM, Hyatt AD, Westbury HA: First virus isolation from Australian fish: an iridovirus-like pathogen from redfin perch, Perca fluviatilis L. J Fish Dis 1986, 9:263-268.

19. Langdon JS: Experimental transmission and pathogenicity of epizootic hematopoietic necrosis virus (EHNV) in redfin perch, Perca fluviatilis L., and 11 other species of teleosts. J Fish Dis 1989, 12:295-310.

20. Moody N, Owens L: Experimental demonstration of the pathogenicity of frog virus, Bohle iridovirus, for a fish species, barramundi, Lates calcarifer . Dis Aquat Organ 1994, 18:95-102.

21. Goorha R: Frog virus 3 DNA replication occurs in two stages. J Virol 1982, 43:519-528.

22. Gravell M, Naegele RF: Nongenetic reactivation of frog polyhedral cytoplasmic deoxyribovirus (PCDV). Virology 1970, 40:170-174.

23. Naegele RF, Granoff A: Viruses and renal carcinoma of Rana pipiens. XI. Isolation of frog virus 3 temperature-sensitive mutants; complementation and genetic recombination. Virology 1971, 44:286-295.

24. Du L, Du Pasquier L, Schwager J, Flajnik MF: The immune system of Xenopus. Annu Rev Immunol 1989, 7:251-275.

25. Tort L, Balasch JC, Mackenzie S: Fish immune system: A crossroads between immune and adaptive responses. Immunologia 2003, 22:277-286.

26. Kaattari SL, Piganelli JD: The specific immune system: humoral defense. The Immune System of Fish: Organism, Pathogen, and Environment San Diego: Academic Press Inclwama G, Nakanishi T 1996, 15.

27. Fellah JS, Kerfourn F, Wiles MV, Schwager J, Charlemagne J: Phylogeny of immunoglobulin heavy chain isotypes: structure of the constant region of Ambystoma mexicanum upsilon chain deduced from cDNA sequence. Immunogenetics 1993, 38:311-317.

28. Hadji-Azimi I: Anuran immunoglobulins. A review. Dev Comp Immunol 1979, 3:233-243.

29. Mussmann R, Wilson M, Marcuz A, Courtet M, Du Pasquier L: Membrane exon sequences of the three Xenopus Ig classes explain the evolutionary origin of mammalian isotypes. Eur J Immunol 1996, 26:409-414.

30. Dworak $L$, Wolfinbarger JB, Bloom ME: Aleutian mink disease parvovirus infection of $\mathrm{K} 562$ cells is antibody-dependent and is mediated via an Fc (gamma)RII receptor. Arch Virol 1997, 142:363-373.

31. Halstead SB, O'Rourke EJ: Dengue viruses and mononuclear phagocytes. I. Infection enhancement by non-neutralizing antibody. J Exp Med 1977 146:201-217.

32. Joseph T, Kibenge MT, Kibenge FS: Antibody-mediated growth of infectious salmon anaemia virus in macrophage-like fish cell lines. J Gen Virol 2003, 84:1701-1710.

33. Kanno $H$, Wolfinbarger JB, Bloom ME: Aleutian mink disease parvovirus infection of mink peritoneal macrophages and human macrophage cell lines. J Virol 1993, 67:2075-2082.

34. Lidbury BA, Mahalingam S: Specific ablation of antiviral gene expression in macrophages by antibody-dependent enhancement of Ross River virus infection. J Virol 2000, 74:8376-8381 
35. Ochiai H, Kurokawa M, Matsui S, Yamamoto T, Kuroki Y, Kishimoto C, Shiraki K: Infection enhancement of influenza A NWS virus in primary murine macrophages by anti-hemagglutinin monoclonal antibody. $J$ Med Virol 1992, 36:217-221.

36. Olsen CW, Corapi W, Ngichabe CK, Baines JD, Scott FW: Monoclonal antibodies to the spike protein of feline infectious peritonitis virus mediate antibody-dependent enhancement of infection of feline macrophages. J Virol 1992, 66:956-965.

37. Porterfield JS: Antibody-dependent enhancement of viral infectivity. Adv Virus Res 1986, 31:335-355.

38. Evenhuis J, Bengten E, Snell C, Quiniou SM, Miller NW, Wilson M: Characterization of additional novel immune type receptors in channel catfish, Ictalurus punctatus. Immunogenetics 2007, 59:661-671.

39. Hawke NA, Yoder JA, Haire RN, Mueller MG, Litman RT, Miracle AL, Stuge T, Shen L, Miller N, Litman GW: Extraordinary variation in a diversified family of immune-type receptor genes. Proc Natl Acad Sci USA 2001, 98:13832-13837.

40. Stafford JL, Wilson M, Nayak D, Quiniou SM, Clem LW, Miller NW, Bengten E: Identification and characterization of a FCR homolog in an ectothermic vertebrate, the channel catfish (Ictalurus punctatus). $J$ Immunol 2006, 177:2505-2517.

41. Yoder JA, Mueller MG, Wei S, Corliss BC, Prather DM, Willis T, Litman RT, Djeu JY, Litman GW: Immune-type receptor genes in zebrafish share genetic and functional properties with genes encoded by the mammalian leukocyte receptor cluster. Proc Natl Acad Sci USA 2001, 98:6771-6776.

42. Strong SJ, Mueller MG, Litman RT, Hawke NA, Haire RN, Miracle AL, Rast JP, Amemiya CT, Litman GW: A novel multigene family encodes diversified variable regions. Proc Natl Acad Sci USA 1999, 96:15080-15085.

43. Albrechtson M, Yeaman GR, Kerr MA: Characterization of the IgA receptor from human polymorphonuclear leucocytes. Immunology 1988, 64.

44. Calabi F, Neuberger MS: Molecular Genetics of Immunoglobulin. New Comprehensive Biochemistry New York: Elsevier Science PublishersNeuberger A, Van Deenen LLM 1987, 17.

45. Delespesse G, Sarfati M, Hofstetter H, Frost H, Kilchherr E, Suter U: Human Fc epsilon R II and IgE-binding factors. Int Arch Allergy Appl Immunol 1989, 88:18-22.

46. Monteiro RC, Kubagawa H, Cooper MD: Cellular distribution, regulation, and biochemical nature of an Fc alpha receptor in humans. J Exp Med 1990, 171:597-613.

47. Ahne W, Bremont M, Hedrick R, Hyatt A, Whittington R: Special topic review: iridoviruses associated with epizootic haematopoietic necrosis (EHN) in aquaculture. World J Microb Biot 1997, 13:367-373.

48. Daszak P, Berger L, Cunningham AA, Hyatt AD, Green DE, Speare R: Emerging infectious diseases and amphibian population declines. Emerg Infect Dis 1999, 5:735-748.

49. Carey C, Cohen N, Rollins-Smith L: Amphibian declines: an immunological perspective. Dev Comp Immunol 1999, 23:459-472.

50. Chinchar VG: Ranaviruses (family Iridoviridae): emerging cold-blooded killers. Arch Virol 2002, 147:447-470.

51. Cunningham AA, Langton TE, Bennett PM, Lewin JF, Drury SE, Gough RE, Macgregor SK: Pathological and microbiological findings from incidents of unusual mortality of the common frog (Rana temporaria). Philos Trans R Soc Lond B Biol Sci 1996, 351:1539-1557.

52. De Voe R, Geissler K, Elmore S, Rotstein D, Lewbart G, Guy J: Ranavirusassociated morbidity and mortality in a group of captive eastern box turtles (Terrapene carolina carolina). J Zoo Wild Med 2004, 35:534-543.

53. Jancovich JK, Davidson EW, Morado JF, Jacobs BL, Collins JP: Isolation of a lethal virus from the endangered tiger salamander Ambystoma tigrinum stebbins. Dis Aquat Organ 1997, 31:161-167.

54. Jancovich JK, Davidson EW, Parameswaran N, Mao J, Chinchar VG, Collins JP, Jacobs BL, Storfer A: Evidence for emergence of an amphibian iridoviral disease because of human-enhanced spread. Mol Ecol 2005, 14:213-224.

55. Zhang QY, Xiao F, Li ZQ, Gui JF, Mao J, Chinchar VG: Characterization of an iridovirus from the cultured pig frog Rana grylio with lethal syndrome. Dis Aquat Organ 2001, 48:27-36.

56. Maniero GD, Morales H, Gantress J, Robert J: Generation of a long-lasting, protective, and neutralizing antibody response to the ranavirus FV3 by the frog Xenopus. Dev Comp Immunol 2006, 30:649-657.
57. Morales HD, Robert J: Characterization of primary and memory CD8 T-cell responses against ranavirus (FV3) in Xenopus laevis. J Virol 2007, 81:2240-2248.

58. Goncalvez AP, Engle RE, St Claire M, Purcell RH, Lai CJ: Monoclonal antibody-mediated enhancement of dengue virus infection in vitro and in vivo and strategies for prevention. Proc Natl Acad Sci USA 2007, 104:9422-9427.

59. Halstead SB: In vivo enhancement of dengue virus infection in rhesus monkeys by passively transferred antibody. J Infect Dis 1979, 140:527-533.

60. Rosen L: Disease exacerbation caused by sequential dengue infections: myth or reality?. Rev Infect Dis 1989, 11(Suppl 4):S840-842.

61. Eaton $\mathrm{H}$, Metcalf J, Brunetti CR: Expression of frog virus 3 genes is impaired in mammalian cell lines. Virol J 2008, 5:83.

62. Laemmli UK: Cleavage of structural proteins during the assembly of the head of bacteriophage T4. Nature 1970, 227:680-685.

doi:10.1186/1743-422X-7-41

Cite this article as: Eaton et al:: Antibody dependent enhancement of frog virus 3 infection. Virology Journal 2010 7:41.

\section{Submit your next manuscript to BioMed Central and take full advantage of:}

- Convenient online submission

- Thorough peer review

- No space constraints or color figure charges

- Immediate publication on acceptance

- Inclusion in PubMed, CAS, Scopus and Google Scholar

- Research which is freely available for redistribution

Submit your manuscript at www.biomedcentral.com/submit
Biomed Central 